\title{
The Role of Platelet Indices in Predicting Short-Term Mortality in Elderly Patients with Pulmonary Embolism
}

\section{Pulmoner Embolisi Olan Yaşlı Hastalarda Kısa Süreli Mortaliteyi Öngörmede Trombosit İndekslerinin Rolü}

\author{
-Serdar Özdemir', @Abdullah Algın ${ }^{1,2}$ \\ 'Department of Emergency Medicine, University of Health Sciences Ümraniye Training and Research Hospital, Istanbul, Turkey \\ 2University of Health Sciences (Turkey), Somalia Mogadishu Recep Tayyip Erdoğan Faculty of Health Sciences, Mogadishu, Somalia
}

\begin{abstract}
Objective: This study aimed to investigate the role of platelet count, mean platelet volume (MPV), plateletcrit, platelet distribution width, platelet mass index (PMI), and MPV-to-platelet ratio (MPR) in predicting short-term mortality in patients aged 65 years and over with pulmonary embolism.
\end{abstract}

Material and Method: This retrospective, observational, cohort study included patients with computed tomography angiography-corrected pulmonary embolism. Demographics, clinical characteristics, platelet indices, and all-cause mortality data within 30 days after admission were noted. The receiver operating characteristic curve and multivariate analyses were performed to determine the discriminative ability of the platelet indices.

Results: A final analysis of 128 patients was performed. The mortality rate was $21.8 \%$. There was no significant relationship in the multivariate analysis between mortality and platelet indices (Mann-Whitney $U$ test). The area under curve values of the neutrophil-to-lymphocyte ratio, PMI, MPR, plateletcrit, platelet count, and MPV were $0.501,0.640,0.626,0.642,0.633$, and 0.532 , respectively.

Conclusion: Based on the results of our sample, the investigated platelet indices were not able to predict short-term mortality in elderly patients with pulmonary embolism.

Keywords: Blood platelets, pulmonary embolism, mean platelet volume, mortality
Öz

Amaç: Çalışmamızda 65 yaş ve üzeri pulmoner emboli hastalarında; trombosit sayısı, ortalama trombosit hacmi (OTH), plateletkrit, trombosit dağılım genişliği, trombosit kitle indeksi (TKI) ve OTHtrombosit sayısı oranının (OTO) kısa dönem mortaliteyi öngörmedeki rolünü araştıımayı amaçladık.

Gereç ve Yöntem: Bu retrospektif, gözlemsel, kohort çalışmasında, bilgisayarlı tomografi anjiyografi ile doğrulanmış pulmoner emboli olan hastalar dahil edilmiş̧ir. Başvurudan sonraki 30 gün içinde tüm nedenlere bağıı̈lüm verileri, demografik, klinik özellikler ve trombosit indeksleri kaydedildi. Trombosit indekslerinin ölümü öngörebilirliğini belirlemek için alııı karakteristik eğrisi ve çok değişkenli analizler yapıldı.

Bulgular:Toplam 128 hastanın son analizi yapıldı. Ölüm oranı \%21,8 idi. Ölüm ile trombosit indeksleri arasında çok değişkenli analizde anlamlı bir ilişki yoktu (Mann-Whitney U testi). Nötrofil-lenfosit oranı, TKI, OTO, plateletkrit, trombosit sayısı ve OTH'nin eğri altındaki alan değerleri sırasıyla 0,501, 0,640, 0,626, 0,642, 0,633 ve 0,532 idi.

Sonuç: Örneklemimizin sonuçlarına göre, trombosit indeksleri pulmoner emboli olan yaşlı hastalarda kısa dönem mortaliteyi öngörmede yeterli değildir.

Anahtar Kelimeler:Trombosit, pulmoner emboli, ortalama trombosit hacmi, mortalite

Corresponding (illetişim): Serdar Özdemir, Department of Emergency Medicine, University of Health Sciences Ümraniye Training and Research Hospital, Istanbul, Turkey

E-mail (E-posta): dr.serdar55@hotmail.com

Received (Geliş Tarihi): 29.08.2021Ａccepted (Kabul Tarihi): 15.09.2021 


\section{INTRODUCTION}

Pulmonary embolism (PE) is a common and often fatal disease. It is the third most common cause of cardiovascular deaths and the most common cause of patient death after surgery. ${ }^{[1]}$ Rapid diagnosis and treatment significantly reduce mortality and long-term complications, such as chronic thromboembolic pulmonary hypertension and cor pulmonale. ${ }^{[2]}$ The clinical features of pulmonary thromboembolism are variable and nonspecific, making an accurate diagnosis and prognostication of poor outcome difficult. There is also no specific laboratory test. Many ancillary diagnostic tests are utilized because medical history and physical examination findings are not sufficient alone to diagnose PE. ${ }^{[2,3]}$ Various clinical scoring systems, including pulmonary embolism severity index (PESI) and simplified PESI or laboratory parameters, such as cardiac troponin I and T, and B-type natriuretic peptide are used in the prognostic evaluation of $\mathrm{PE} .^{[3]}$

Platelets are granular cells with a diameter of 2-4 microns. They play a key role in hemostasis and coagulation. ${ }^{[4]}$ The glycoprotein coat covering the platelet membrane surface ensures that the platelet adheres to the damaged vessel endothelium. This cover is especially responsible for binding to the damaged endothelial cells and the collagen released in the vessel wall. ${ }^{[4]}$ In addition, phospholipids in the platelet membrane activate the intrinsic pathway in coagulation. ${ }^{[4]}$ The risk of venous thromboembolism increases with age, and it is approximately 10 times greater in individuals aged over 80 years compared to those aged $45-50$ years. ${ }^{[5]}$ Based on this information, we hypothesized that platelet indices might be associated with prognosis in thromboembolic diseases, such as PE in the later decades of life.

In this study, we aimed to investigate the role of platelet count, mean platelet volume (MPV), plateletcrit, platelet distribution width (PDW), platelet mass index (PMI), and MPV-to-platelet ratio (MPR) in predicting short-term mortality in patients aged 65 years and over with PE.

\section{MATERIAL AND METHOD}

\section{Study Design}

Our retrospective observational study was conducted at the emergency department (ED) of a 721-bed tertiary education hospital receiving $961 \mathrm{ED}$ admissions per day (annual average of the study period). The data of the patients presenting to the ED with PE signs and symptoms over the four-year study period (between June 15, 2017 and June 1, 2021) were gathered retrospectively.

\section{Study Population}

The population of this study consisted of patients presenting to our ED with PE signs and symptoms between June 15, 2017 and June 1, 2021. Patients under 65 years those for whom PE could not be confirmed with computerized tomography angiography (CTA), and those with missing data were excluded. Figure 1 shows the flow chart of the study.

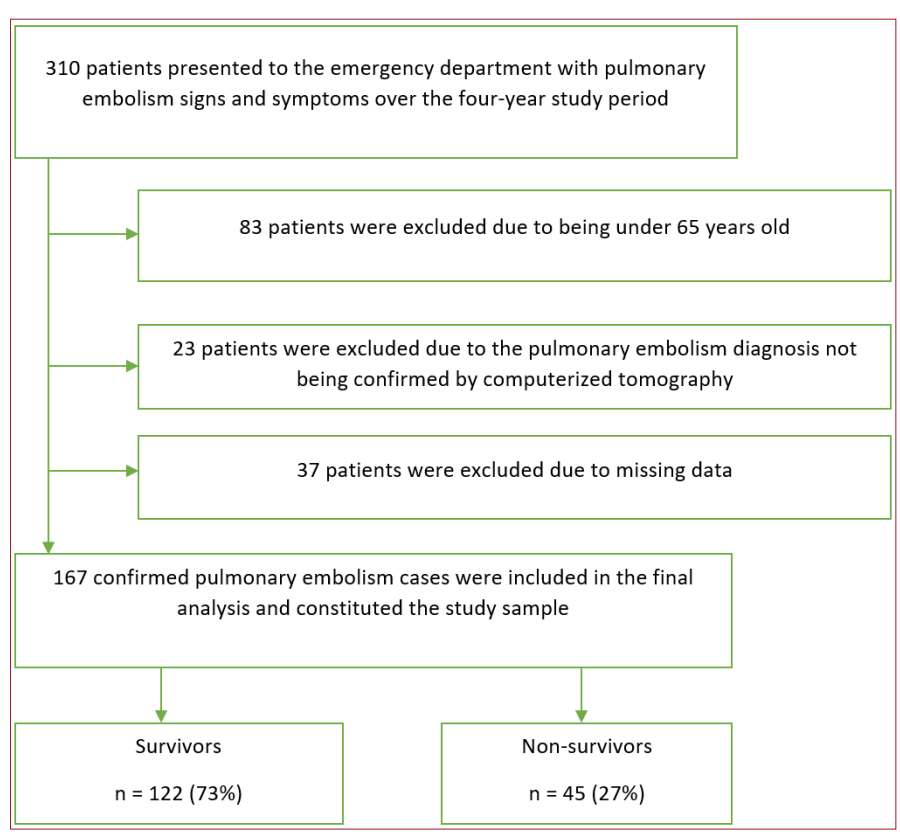

Figure 1. Flow chart of the study

\section{Data Collection}

The demographic data (age, gender), symptoms, ED triage tags, and laboratory parameters of the study sample were collected from the computer-based data system of the hospital. The symptoms of patients were noted as chest pain, hemoptysis, shortness of breath, weakness, muscle-joint pain (leg), back pain, stomachache, palpitation, nausea-vomiting, and syncope. The ED triage tags of the patients were recorded as red, yellow, and green. The following laboratory parameters were evaluated: white blood cell count, neutrophil count, neutrophil ratio, monocyte count, monocyte ratio, lymphocyte count, lymphocyte ratio, hemoglobin, hematocrit, mean corpuscular volume, red cell distribution weight, platelet count, MPV, plateletcrit, PDW, neutrophil-to-lymphocyte ratio (NLR), MPR, and PMI. The PMI values were calculated by multiplying the platelet count and MPV.

\section{Statistical Analysis}

Microsoft Excel was used for the frequency analysis, and the remaining statistical analyses were conducted using SPSS version 22.0 for Windows (SPSS Inc, Chicago, IL, USA). The conformity of data to the normal distribution was evaluated with the Kolmogorov-Smirnov test. Interquartile range (25th75th percentile values) and median were used to present quantitative variables. The Mann-Whitney test was used to compare quantitative variables. To report the independent predictors of mortality, we performed a multivariate analysis of the factors determined to be significant in the univariate analyses and demographics.

The accuracy of the evaluated platelet indices in predicting short-term mortality was evaluated using the receiver operating characteristic (ROC) curves. The results of the ROC curves were presented as the area under the curve (AUC) 
values. A good predictor should have an AUC value above 0.8 . An AUC value closer to 1 indicates a better predictor. The optimal cut-off values of the platelet indices with the best specificity and sensitivity were determined using Youden's index. We used the DeLong equality test to test the differences between the AUC values of the platelet indices. $P$ values below 0.05 were considered statistically significant.

\section{Ethics}

Approval for the study was obtained from the local ethics committee with (approval date: 08/25/2021, number 255). Due to the retrospective design of the study and the sample not including any personal data, informed consent was waived within the knowledge of the ethics committee.

\section{RESULTS}

A final analysis of 128 patients was performed after applying the inclusion and exclusion criteria. Forty-nine (38.3\%) patients were male. The median age of the enrolled patients was 79 (IQR: 66-80) years. A total of 28 patients died, and the mortality rate was $21.8 \%$. Table 1 presents the baseline characteristics of the enrolled patients and the comparison of the characteristics between the survivor and non-survivor groups. The green triage tag was assigned to $23(18 \%)$ patients had, the yellow triage tag to $30(23.4 \%)$ patients, and the red triage tag to 75 $(58.6 \%)$ patients. Of the surviving patients, $23(23 \%)$ had the green triage tag, $28(28 \%)$ had the yellow triage tag, and 49 (49\%) had the red triage tag. Of the non-survived patients, none had the green triage tag, while two $(7.1 \%)$ had the yellow triage tag and 26 (92.9) had the red triage tag. There was a statistically significant difference between the survivor and non-survivor groups in terms of the triage tag (chi-square test, $\mathrm{p}<0.001$ ).
Table 2 shows the laboratory parameters of the enrolled patients and their comparison between the survivor and non-survivor groups. Significant differences were detected between the survivor and non-survivor groups in terms of platelet count [206 (149-259) versus 241 (192-317), $\mathrm{p}=0.033$ ]. However, the relationship between platelet count and mortality was not significant according to the multivariate analysis (Table 3) (Mann-Whitney $U$ test, $p=0.756$ ). The AUC values of NLR, PMI, MPR, plateletcrit, platelet count, and MPV were determined as $0.501,0.640,0.626,0.642,0.633$, and 0.532 , respectively (Table 4, Figure 2 ).

\begin{tabular}{|c|c|c|c|c|}
\hline \multirow{2}{*}{ Variables } & Total & Survivors & $\begin{array}{c}\text { Non- } \\
\text { survivors }\end{array}$ & \multirow{2}{*}{$\underset{\text { values }}{\mathbf{p}}$} \\
\hline & $\begin{array}{c}n=128(\%, \\
\text { min-max) }\end{array}$ & $\begin{array}{c}n=100 \\
(78.1 \%)\end{array}$ & $\begin{array}{c}n=28 \\
(21.9 \%)\end{array}$ & \\
\hline Age, years & $79(66-80)$ & $76(69-82)$ & $81(77-88)$ & 0.305 \\
\hline Gender & & & & 0.573 \\
\hline Male & 49 (38.3\%) & 37 (37\%) & $12(42.9 \%)$ & \\
\hline Female & 79 (61.7\%) & $63(63 \%)$ & $16(57.1 \%)$ & \\
\hline Frequency of symptoms & & & & 0.961 \\
\hline Chest pain & 14 (10.9\%) & $14(14 \%)$ & 0 & \\
\hline Hemoptysis & $9(7 \%)$ & 7 (7\%) & $2(7.1 \%)$ & \\
\hline Shortness of breath & $59(46.1 \%)$ & $46(46 \%)$ & $13(46.4 \%)$ & \\
\hline Weakness & $9(7 \%)$ & 7 (7\%) & $2(7.1 \%)$ & \\
\hline Muscle-joint pain (leg) & $7(5.5 \%)$ & $6(6 \%)$ & $1(3.6 \%)$ & \\
\hline Back pain & $5(3.9 \%)$ & $5(5 \%)$ & 0 & \\
\hline Stomachache & $3(2.3 \%)$ & 0 & $3(10.7 \%)$ & \\
\hline Palpitation & $7(5.5 \%)$ & $5(5 \%)$ & $2(7.1 \%)$ & \\
\hline Nausea-vomiting & $2(1.6 \%)$ & $2(2 \%)$ & 0 & \\
\hline Syncope & $13(10.2 \%)$ & $10(10 \%)$ & $3(10.7 \%)$ & \\
\hline Triage tag & & & & $<0.001$ \\
\hline Green & $23(18 \%)$ & $23(23 \%)$ & 0 & \\
\hline Yellow & $30(23.4 \%)$ & $28(28 \%)$ & $2(7.1 \%)$ & \\
\hline Red & $75(58.6 \%)$ & 49 (49\%) & $26(92.9)$ & \\
\hline
\end{tabular}

\section{Table 2. Laboratory parameters of the enrolled patients and their comparison between the survivor and non-survivor groups}

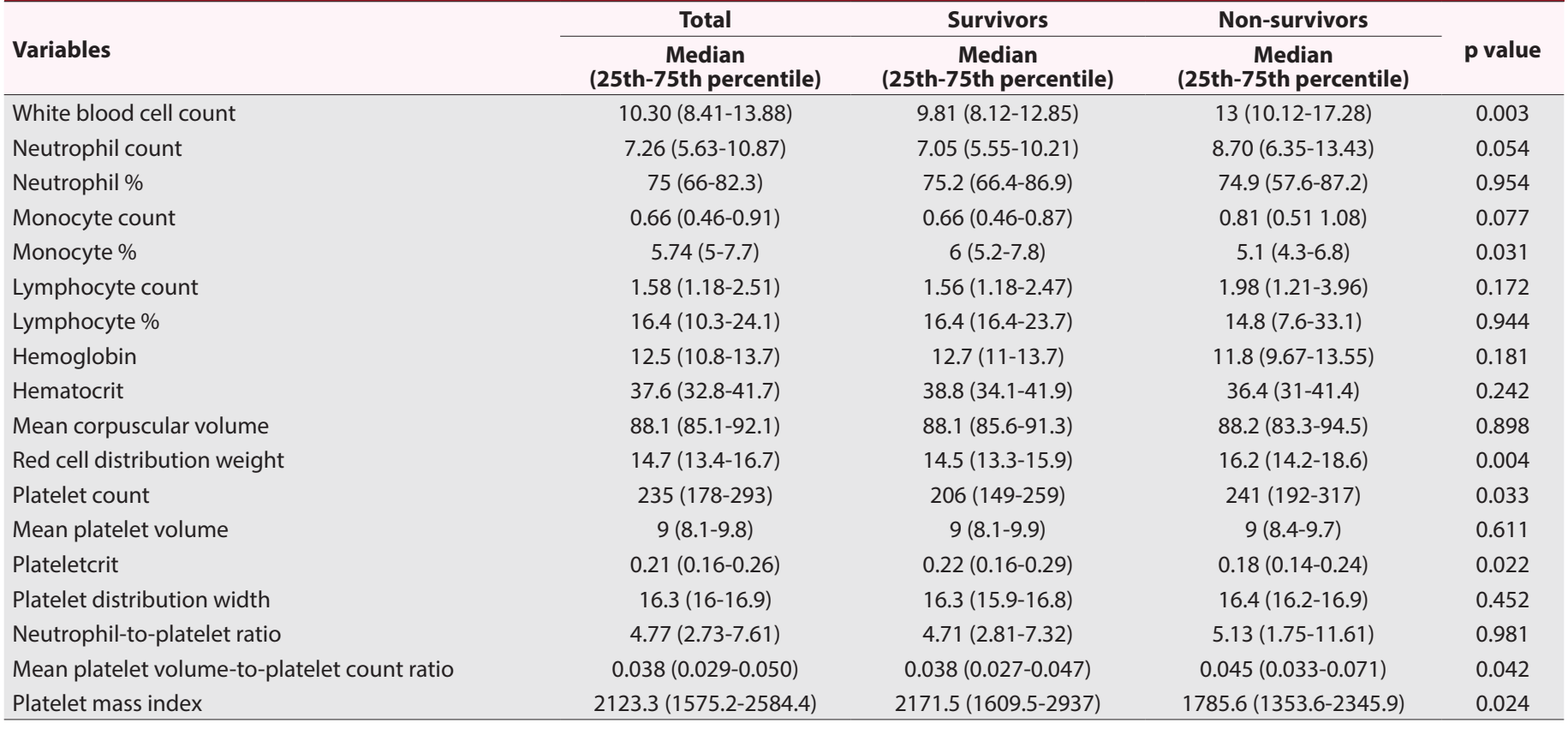


Table 3. Results of the univariate and multivariate logistic regression analyses

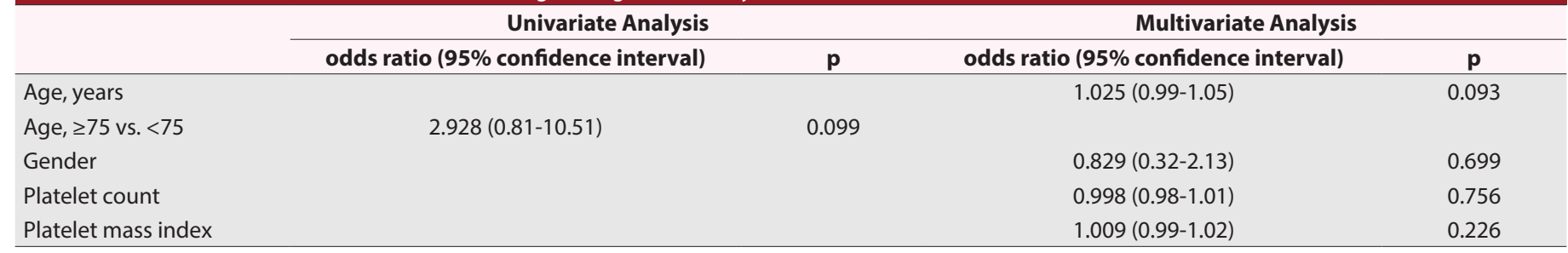

\begin{tabular}{|c|c|c|c|c|c|c|c|c|c|c|c|}
\hline & AUC & Cut-off & Sensitivity & Specificity & PPV & NPV & LR+ & LR- & Accuracy & $95 \% \mathrm{Cl}$ & p-value \\
\hline NLR & 0.501 & $>1.59$ & 75 & 7.07 & 18.6 & 50.0 & 0.81 & 3.54 & 17.93 & $41.1-59.1$ & 0.984 \\
\hline PMI & 0.640 & $\leq 1966.2$ & 64.3 & 61.6 & 32.1 & 85.9 & 1.67 & 0.58 & 25.90 & $55.0-72.4$ & 0.019 \\
\hline Plateletcrit & 0.642 & $\leq 0.18$ & 57.1 & 66.7 & 32.7 & 84.6 & 1.71 & 0.64 & 23.81 & $55.2-72.5$ & 0.018 \\
\hline Platelet count & 0.633 & $\leq 212$ & 60.7 & 62.6 & 31.5 & 84.9 & 1.62 & 0.63 & 23.34 & $54.2-71.6$ & 0.032 \\
\hline
\end{tabular}

AUC: area under the curve; PPV: positive predictive value; LR: likelihood ratio; Cl: confidence interval; NPV: negative predictive value; NLR: neutrophil-to-lymphocyte ratio; PMI: platelet mass index; MPR: mean platelet volume-to-platelet count ratio; MPV: mean platelet volume

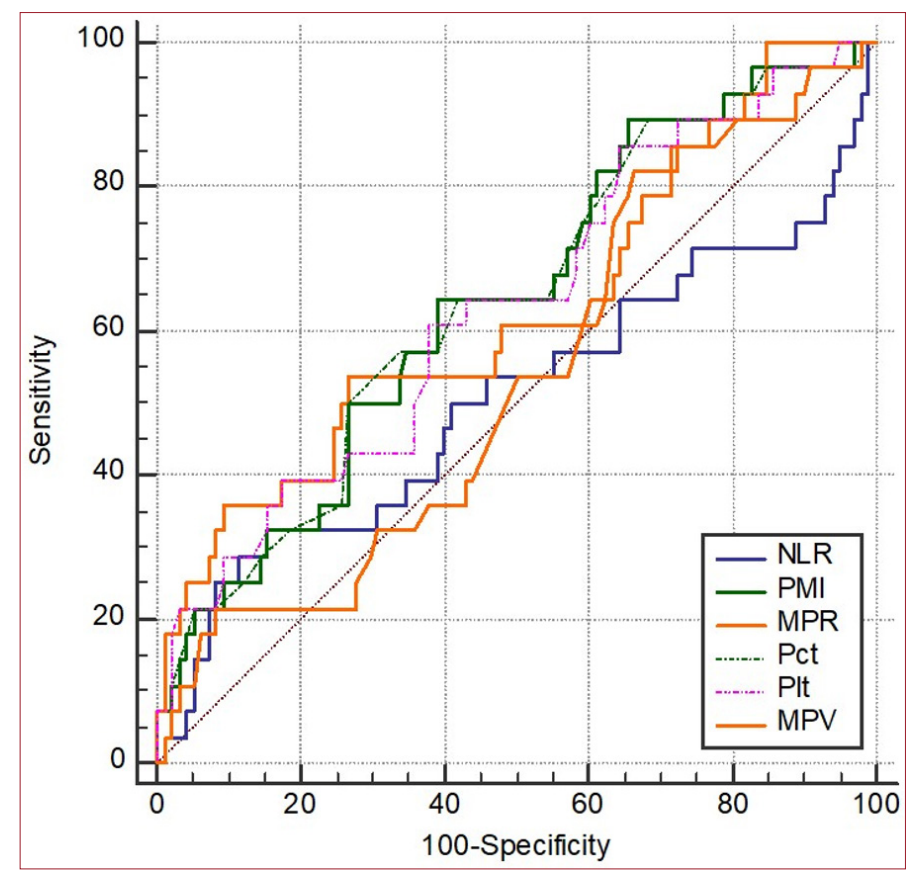

Figure 2. Receiver operating characteristic curves of the investigated laboratory parameters for the prediction of 30-day mortality in all patients aged 65 years and over with pulmonary embolism

\section{DISCUSSION}

This study examined the predictive ability of platelet indices for short-term mortality in elderly patients with PE and revealed no statistically significant difference between the survivor and non-survivor groups in the terms of any of the indices except for platelet count. To the best of our knowledge, this is the first study to investigate the predict ability of PMI in short-term mortality in elderly patients with PE.

Platelet count and MPV are inexpensive and easy-tomeasure parameters used in most routine clinical practices. Platelet count and other platelet indices, including PDW, plateletcrit, and MPV increase in thromboembolic events.
[6] Physiologically, there is an inverse relationship between MPV and platelet count. ${ }^{[6]}$ There is evidence that MPV is an important risk factor for arterial thrombosis, acute myocardial infarction, diabetes, and venous thromboembolism. ${ }^{[7]}$ It is also known that the MPV value is higher in the acute phase of venous and arterial thrombosis, and this leads to poor clinical outcomes. ${ }^{[6,7]}$ It has been shown that larger platelets are younger, have contain granules, adhesion receptor expression, are more enzymatically and metabolically active, aggregate more rapidly with collagen, and therefore have increased thrombogenic properties. ${ }^{[8]}$ This can be explained by the migration of platelets to a larger population and a higher proportion of immature platelets in peripheral blood. ${ }^{[9]}$ Considering the high level of platelet turnover at the time of thrombus formation, platelets released into the circulation are more thrombogenic in their natural environment, ${ }_{1}^{[9]}$ which is the reason for undesirable prognosis associated with higher levels of MPV in the PE setting. ${ }^{[10]}$ Significantly increased MPV has been reported in different meta-analyses of various clinical conditions. ${ }^{[1]}$ A meta-analysis reported significantly increased MPV and significantly decreased platelet count in thromboembolism..$^{[1]}$ However, further studies are required to determine whether increased MPV in thromboembolic events is the cause or result of venous occlusion.

PMI and MPR, which is a combination of platelet count and MPV, have been investigated in different clinical situations by different researchers. ${ }^{[12-16]}$ It has suggested that low PMI and high MPR values may be associated with the inflammatory process. We consider that neither parameter being determined as a good predictor of mortality in our sample may be because platelet count and MPV were already resulted negatively in our sample.

Plateletcrit is the ratio of the volume of platelets to the total blood volume, and it is an indicator of total platelet mass. ${ }^{[17]} \mathrm{It}$ is generally correlated with MPV and PDW. Increased plateletcrit has been associated with poor prognosis in thromboembolic 
events. ${ }^{[17,18]}$ Possible explanations in the literature include thrombus formation due to exaggerated platelet activity and increased blood viscosity and aggregability resulting in increased plateletcrit. ${ }^{[18]}$

Since PDW is a specific platelet activation marker, it has been reported to increase in thromboembolic events. ${ }^{[19,20]}$ Several other possible mechanisms have been suggested for the increase in PDW in thromboembolic events. One of the theories is platelets being larger in bone marrow due to increased platelet destruction. Another possible explanation is platelet enlargement secondary to hypoxemia and platelet activation. ${ }^{[20]}$

\section{Limitations}

The most important limitation of our study is that it was conducted retrospectively. Secondly, the single-center nature of our study reduces its generalizability. Another important limitation is that the PE cases could not be classified as high, intermediate, and low risk. Our study was a negative resulted study. However, the small sample size may be the reasons for from the absence of significant results; therefore, we recommend further multicenter studies with larger cohorts.

\section{CONCLUSION}

Based on the results of our sample, the evaluated platelet indices were not able to predict short-term mortality in elderly patients with PE. However, we recommend multicenter prospective studies with larger cohorts to validate the results of our study.

\section{ETHICAL DECLARATIONS}

Ethics Committee Approval: Approval for the study was obtained from the local ethics committee with (approval date: 08/25/2021, number 255).

Informed Consent: Because the study was designed retrospectively, no written informed consent form was obtained from patients.

Referee Evaluation Process: Externally peer-reviewed.

Conflict of Interest Statement: The authors have no conflicts of interest to declare.

Financial Disclosure: The authors declared that this study has received no financial support.

Author Contributions: All of the authors declare that they have all participated in the design, execution, and analysis of the paper, and that they have approved the final version.

\section{REFERENCES}

1. Turetz M, Sideris AT, Friedman OA, Triphathi N, Horowitz JM. Epidemiology, Pathophysiology, and Natural History of Pulmonary Embolism. Semin Intervent Rsadiol. 2018;35(2):92-98.

2. Opitz I, Ulrich S. Chronic thromboembolic pulmonary hypertension. Swiss Med Wkly. 2018 Dec 21;148:w14702.

3. Surov A, Akritidou M, Bach AG, et al. A New Index for the Prediction of 30-Day Mortality in Patients with Pulmonary Embolism: The Pulmonary Embolism Mortality Score (PEMS). Angiology. 2021;72(8):787-93.
4. Periayah $\mathrm{MH}$, Halim AS, Mat Saad AZ. Mechanism Action of Platelets and Crucial Blood Coagulation Pathways in Hemostasis. Int J Hematol Oncol Stem Cell Res. 2017;11(4):319-27.

5. Tsai AW, Cushman M, Rosamond WD, Heckbert SR, Polak JF, Folsom AR. Cardiovascular risk factors and venous thromboembolism incidence: the longitudinal investigation of thromboembolism etiology. Arch Intern Med. 2002 May 27;162(10):1182-9.

6. Budak YU, Polat M, Huysal K. The use of platelet indices, plateletcrit, mean platelet volume and platelet distribution width in emergency non-traumatic abdominal surgery: a systematic review. Biochem Med (Zagreb). 2016;26(2):178-93.

7. Braekkan SK, Mathiesen EB, Njølstad I, Wilsgaard T, Størmer J, Hansen JB. Mean platelet volume is a risk factor for venous thromboembolism: the Tromsø Study, Tromsø, Norway. J Thromb Haemost. 2010;8(1):157-62.

8. Yun SH, Sim EH, Goh RY, Park Jl, Han JY. Platelet Activation:The Mechanisms and Potential Biomarkers. Biomed Res Int. 2016;2016:9060143.

9. Thon JN, Montalvo A, Patel-Hett S, et al. Cytoskeletal mechanics of proplatelet maturation and platelet release. J Cell Biol. 2010 Nov 15;191(4):861-74.

10. Lin W, Wu Y, Lu X, Hu Y. Association between mean platelet volume and pulmonary embolism: a systematic review and meta-analysis. Aging (Albany NY). 2021;13(13):17253-73.

11. Ren ZJ, Ren PW, Yang B, et al. Mean platelet volume, platelet distribution width and platelet count in erectile dysfunction: A systematic review and meta-analysis. Andrologia. 2017;49(10).

12. Kahvecioglu D, Erdeve $\mathrm{O}$, Akduman $\mathrm{H}$, et al. Influence of platelet count, platelet mass index, and platelet function on the spontaneous closure of ductus arteriosus in the prematurity. Pediatr Neonatol. 2018;59(1):53-7.

13. Okur N, Buyuktiryaki M, Uras N, et al. Platelet mass index in very preterm infants: can it be used as a parameter for neonatal morbidities? J Matern Fetal Neonatal Med. 2016;29(19):3218-22.

14. Korkmaz L, Baştuğ O, Ozdemir A, et al. The Efficacy of Propranolol in Retinopathy of Prematurity and its Correlation with the Platelet Mass Index. Curr Eye Res. 2017;42(1):88-97.

15.Zhong Q, Peng J. Mean platelet volume/platelet count ratio predicts severe pneumonia of COVID-19. J Clin Lab Anal. 2021;35(1):e23607.

16. Ates $\mathrm{H}$, Ates I, Kundi H, Yilmaz FM. Diagnostic validity of hematologic parameters in evaluation of massive pulmonary embolism. J Clin Lab Anal. 2017;31(5):e22072.

17. Erdal E, İnanir M. Platelet-to-lymphocyte ratio (PLR) and Plateletcrit (PCT) in young patients with morbid obesity. Rev Assoc Med Bras (1992). 2019;65(9):1182-7.

18. Çakmak HA, Enhoş A, Ertürk M, Kalkan AK, Satılmışoğlu MH, Gül M. Association Between New Platelet Indices and Calcific Aortic Stenosis: Plateletcrit And Platelet to Lymphocyte Ratio. Van Med J. 2016;23(4):3307.

19. Gasparyan AY, Ayvazyan L, Mikhailidis DP, Kitas GD. Mean platelet volume: a link between thrombosis and inflammation? Curr Pharm Des. 2011;17(1):47-58.

20. Sevuk U, Bahadir MV, Altindag R, et al. Value of serial platelet indices measurements for the prediction of pulmonary embolism in patients with deep venous thrombosis. Ther Clin Risk Manag. 2015;11:1243-9. 